\title{
HUMAN PSYCHOLOGICAL FACTORS IN THE SUCCESS OF HUMAN CAPITAL INVESTMENT IN DRIVING FINANCIAL PERFORMANCE, CASE STUDY OF THE HOTEL INDUSTRY IN INDONESIA AND MALAYSIA
}

Diah RUSMINGSIH ${ }^{1 *}$ Eny Lestari WIDARNI² Suryaning BAWONO ${ }^{3}$

Received: January 2021 | Accepted: February 2021 | Published: April 2021

Please cite this paper as: Rusmingsih, D., Widarni, E.L., Bawono, S. (2021) Human psychological factors in the success of human capital investment in driving financial performance, case study of the hotel industry in Indonesia and Malaysia, Holistica Journal of Business and Public Administration, Vol. 12, Iss. 1, pp.69-75

\begin{abstract}
This research combines quantitative research to calculate data variables and draw conclusions as well as meaning-based qualitative research for things that are observed and cannot be calculated precisely such as psychological factors in human resources and other human factors related to human capital investment and organizational performance in Hotel Industry throughout Indonesia and Malaysia. With careful observation based on activity reports and various reliable sources using content analysis, we find that investment in human capital can be successful if human factors of human resources can be fulfilled such as comfort and job satisfaction. So that the factors of expertise and work comfort are the two dominant factors in increasing the success of investing in human capital in improving organizational work.
\end{abstract}

Keywords: Human Psychological; Human Capital Investment; Hotel Industry; Financial Performance

\footnotetext{
${ }^{1}$ STIE Jaya Negara Taman Siswa Malang, Jl.Tumenggung Suryo No.17 (Tamansiswa Area) Malang, East Java, Indonesia, diahrusmingsih@stiekn.ac.id.

* Corresponding author.

2 STIE Jaya Negara Taman Siswa Malang, JI.Tumenggung Suryo No.17 (Tamansiswa Area) Malang, East Java, Indonesia, enylestariwidarni@stiekn.ac.id.

${ }^{3}$ STIE Jaya Negara Taman Siswa Malang, Jl.Tumenggung Suryo No.17 (Tamansiswa Area) Malang, East Java, Indonesia, nino@stiekn.ac.id.
} 


\section{Introduction}

In human capital management, new ideas, frameworks and theories have sprung up to replace old ideas, frameworks and theories. However, that does not mean that the old theory cannot be applied in the real world.

Strategic Human Resources can not only hold from the perspective of human resources. Still, they must integrate the perspectives of other scientists to study the characteristics of people in the organization and how these characteristics affect company performance in the field of Strategic Human Resource Management. One of the perspectives used in this case is a psychological perspective (Boxall, 2015; Wright, 2020). Human resource management practices can affect the psychological processes of human resources being managed, such as changes in personnel commitment to the organization, organizational personnel behaviour, and other factors that can affect company performance. The human capital theory is a comprehensive framework in managing and developing human resources to improve organizational performance. Human capital in practice uses a psychological basis on how the practice of managing human resources owned by a company or organization to improve the performance of the company. So that human capital investment can also use a financial perspective in calculating the costs incurred and the benefits that the organization gets from the results of human capital investment. Based on organizational performance, including financial performance.

This study combines financial and human resource management perspectives in encouraging organizational performance by taking into account the psychological factors of the workforce by using a combination of quantitative and qualitative methods in analysing the object of research.

\section{Literature review}

Human resources have at least five main elements, namely, knowledge, information, ideas, skills, and health. These five elements influence individual performance in providing value or contribution to the organization (Machado \& Davim, 2017 ; Fonseca,et al.,2019).

Social capital explains how a working relationship within an organization can make individuals feel valuable to the company. Social capital is defined as a network of individuals who provide value to the group of individuals, and these groups of individuals develop cooperative relationships to help each other improve coordination and cooperation in completing work together. Social capital is significant in the formulation of a human capital strategy (Greenberg, et al., 2016; Rodgers,et al.,2020).

The human capital theory explains how individuals or people develop the knowledge, skills and abilities that individuals have in completing their work or contribute to the organization and how these individuals make choices to invest their energy, thoughts and money in increasing knowledge, skills and knowledge and health. Which becomes human 
capital for him to increase his contribution to the organization. Psychological and economic perspectives are integrated into developing a human capital framework where the human capital model is based on a psychological perspective in understanding the needs of human development in a group to become a source of economic competitive advantage either by increasing human capital in each individual or social capital that develops in the group Silva, et al., 2020; Elo \& Coy, 2018). In this study, individuals are assumed to make decisions and be rational in providing the best for themselves or the personnel. Human capital analysis can begin with the assumption that each individual weighs the benefits and costs incurred in developing education, training, health and wellbeing to provide the best for themselves.

Human Resources can be improved through education, training and experience mechanisms in the form of developing individual knowledge, skills and abilities, so that individuals can develop their abilities to give their best performance and get fair compensation for the contribution or performance has given. Individuals with low human capital tend to have a low contribution to the company or organization so that the income generated by these individuals is also low (Boella \& Turner, 2013; Lee \& Kartika, 2014).The human capital investment serves to increase human capital in individuals to increase their contribution to the organization.

Human resources (HRM) are responsible for shaping organizational behaviour and culture (Blake \& Gano-an, 2020). In investing in human capital, training in increasing social capital in this case work group cohesiveness can be done (Suprapto \& Verdyana, 2020).

In addition to expertise and knowledge to improve individual performance in organizations, human capital has other aspects, namely individual health both mentally and physically. So that human capital investment is not only in training and education. But also work equipment and supporting facilities for employee health and the safety and comfort of the work environment.

\section{Research Method}

In this study, we used content analysis which is a research method to identify patterns in the literature that can be trusted to be true. To conduct content analysis, it is systematically recorded from a set of texts, which can be written, spoken, or visual. This study combines qualitative content analysis from a collection of written, oral and visual texts to conclude with quantitative content analysis using secondary data collected during the study period which is estimated using Vector Error Correction Models to see the relationship of human capital investment and financial performance in the hotel industry in Indonesia and Malaysia. We use and collect secondary data from world banks. 


\section{Results}

In this study, we estimate human capital investment and financial performance with VECM to see the relationship between human capital investment and financial performance in the hotel industry in Indonesia and Malaysia. Here we present our estimation results:

Estimation result of VECM Hotel Industry in Indonesia

Estimation Proc:

EC(C,1) 12 HC_INVESTMENT PERFORMANCE

VAR Model:

D(HC_INVESTMENT $)=A(1,1) *(B(1,1) * H C$ INVESTMENT $(-1)+B(1,2) *$ PERFORMANCE $(-1)+$ $\mathrm{B}(1,3))+\mathrm{C}(1,1) * \mathrm{D}(\mathrm{HC}$ INVESTMENT(-1)) + $\mathrm{C}(1,2) * \mathrm{D}($ HC_INVESTMENT $(-2))+$ $C(1,3) *$ D (PERFORMANCE $(-1))+C(1,4) *$ D(PERFORMANCE $(-2))+C(1,5)$

$D($ PERFORMANCE $)=A(2,1) *(B(1,1) * H C$ INVESTMENT $(-1)+B(1,2) *$ PERFORMANCE $(-1)+$ $\mathrm{B}(1,3))+\mathrm{C}(2,1) * \mathrm{D}(\mathrm{HC}$ INVESTMENT(-1)) $+\mathrm{C}(2,2) * \mathrm{D}($ HC_INVESTMENT(-2)) + $\mathrm{C}(2,3) * \mathrm{D}$ (PERFORMANCE $(-1))+\mathrm{C}(2,4) * \mathrm{D}($ PERFORMANCE $(-2))+\mathrm{C}(2,5)$

VAR Model - Substituted Coefficients:

$\mathrm{D}($ HC_INVESTMENT) $\quad=\quad-1.58171658375 *($ HC_INVESTMENT(-1) 0.02016226776 *PERFORMANCE(-1) $+2245994955.84 \quad)+$ $0.223274479421 *$ D(HC_INVESTMENT(-1)) + 0.099665941743*D(HC_INVESTMENT(-2)) $0.0393459801088 *$ D (PERFORMANCE(-1)) $\quad-0.040877354468 *$ D (PERFORMANCE(-2)) + 2743613162.56

$\mathrm{D}$ (PERFORMANCE) = $1.9235368392 *($ HC_INVESTMENT(- 1$)$ 0.02016226776 *PERFORMANCE(-1) $+2245994955.84 \quad)+$ $0.57260681394 * \mathrm{D}\left(\right.$ HC_INVESTMENT(-1)) $-0.250775867435^{*} \mathrm{D}($ HC_INVESTMENT(-2)) + $0.407697179819 *$ D(PERFORMANCE(-1)) $\quad$ 0.0296231387084*D(PERFORMANCE(-2)) + 22218496829.6

Estimation result of VECM Hotel Industry in Malaysia

Estimation Proc:

EC(C,1) 12 HC_INVESTMENT PERFORMANCE

VAR Model:

$D($ HC_INVESTMENT $)=A(1,1) *(B(1,1) * H C$ INVESTMENT $(-1)+B(1,2) *$ PERFORMANCE $(-1)+$ $\mathrm{B}(1,3))+\mathrm{C}(1,1) * \mathrm{D}(\mathrm{HC}$ INVESTMENT(-1)) $+\mathrm{C}(1,2) * \mathrm{D}(\mathrm{HC}$ INVESTMENT(-2)) + $\mathrm{C}(1,3) *$ D(PERFORMANCE $(-1))+\mathrm{C}(1,4) * \mathrm{D}($ PERFORMANCE $(-2))+\mathrm{C}(1,5)$

$D($ PERFORMANCE $)=A(2,1) *(B(1,1) *$ HC_INVESTMENT $(-1)+B(1,2) *$ PERFORMANCE $(-1)+$ $\mathrm{B}(1,3))+\mathrm{C}(2,1) * \mathrm{D}(\mathrm{HC}$ INVESTMENT(-1)) + $\mathrm{C}(2,2) * \mathrm{D}($ HC_INVESTMENT(-2)) + $C(2,3) * D($ PERFORMANCE $(-1))+C(2,4) * D($ PERFORMANCE $(-2))+C(2,5)$ 
VAR Model - Substituted Coefficients:

$\mathrm{D}(\mathrm{HC}$ IINVESTMENT) = - $1.41537887744 *(\quad \mathrm{HC}$ INVESTMENT(-1) -

0.00622326904941 *PERFORMANCE $(-1)+1161024920.97 \quad$ +

$0.561207171305 * \mathrm{D}($ HC_INVESTMENT(-1)) $+0.225183681224 * \mathrm{D}($ HC_INVESTMENT(-2)) -

$0.0632325827389 * \mathrm{D}($ PERFORMANCE(-1)) - $0.189394184287 * \mathrm{D}($ PERFORMANCE $(-2))$ + 2890045852.71

$\mathrm{D}($ PERFORMANCE $) \quad=\quad 0.385914913122 *(\quad$ HC_INVESTMENT(-1)

0.00622326904941 *PERFORMANCE $(-1)+1161024920.97 \quad)$ -

$1.66249827625^{*} \mathrm{D}(\mathrm{HC}$ INVESTMENT(-1)) $-0.900481301748 * \mathrm{D}($ HC_INVESTMENT(-2)) +

$0.0527699632551 * \mathrm{D}($ PERFORMANCE $(-1))+0.1408436942 * \mathrm{D}($ PERFORMANCE $(-2))+$ 10125059687.6

From the VECM estimation results for the hotel industry in Indonesia and Malaysia, it can be seen that the relationship or correlation between human capital investment and organizational financial performance is unidirectional where each addition or reduction in human capital investment has the same direction. The same effect is visible, as reducing and increasing human capital investment with different rates of change over time. Behind the difference in the influence of the success of human capital on organizational financial performance, there is a level of humanist factors that play a major role in improving the performance of human resources in encouraging organizational financial performance. Human capital investment is an investment in humans, the humanist factor greatly determines the success of human capital investment. From the estimation results, human capital investment in education and training has an impact on performance. However, qualitatively, it can be seen that humanistic factors such as psychological factors in human resources play an important role in the success of the human capital investment.

\section{Discussion}

In analysing and understanding the object of research, this study uses qualitative content analysis to conclude the content analysis so that it becomes a complete understanding, and uses quantitative content analysis to support the conclusions of qualitative content analysis.

\section{Qualitative Content Analysis}

We conclude there are four psychological factors from individuals who work for organizations that need to be considered in increasing success in human capital investment, namely free will, Identity, Community, Value and Fairly Compensation.

Free will

Every individual has the right and is, normally, entitled to the freedom to make decisions and do his best for himself as long as it does not interfere and harm the interests and rights of others. So, it can be assumed that humans as resources have free will to follow 
organizational rules or not, with a series of logical consequences. So, in order to manage human resources, organizational instruments in the form of regulations and roles are needed to manage human resources optimally.

Each individual is faced with a choice of activities every day, with the same time capital, namely 24 hours a day. Each individual must manage his time properly directing what is expected and considered the best for him. Investments in human capital are not only carried out by organizations but also by individuals who carry out organizational activities. They invest their time, energy and thought to improve the skills needed so that they can contribute more to the organization and should be compensated fairly.

Identity

Identity is the self-view of oneself or how a person describes himself. Each individual has his own perspective on himself and that becomes his identity in making decisions and actions every day. A person's identity can be linked to his or her organization so that the human resource manager has an important role in directing the perspective of employees towards the company to build a self-identity that is tied to the organization so that a sense of pride, joy and enthusiasm arises in working for the organization. In this case, the human resource manager can form the identity of each individual in the organization through internal marketing or marketing within the company itself where internal marketing is the process of planting the company's image and attachment to individuals who work within the company through incentives, career paths and job satisfaction improvement programs.

\section{Community}

Community is an important asset in building social capital. Social capital is very important in human capital, because the perfecter of organizational rules and roles is social capital. Without good social capital, it will be difficult to build a solid and strong team. Social capital can be built with a community approach and social processes where organizations need to invest in building good working relationships in addition to rules and standard operating procedures as well as joint holiday programs or joint sports to build intimacy between individuals in the hope that social capital can be developed properly. One of the components that need to be included in the human capital strategy is the development of social capital, because human capital is integrated with humans themselves. Social capital and good working relations can optimize the human capital that exists in each individual.

Value and Fairly Compensation

Every human being who contributes to the organization as much as the capital owned is optimized by the social capital formed within the company organization itself. Human capital in a company is calculated based on the employee's performance or contribution to the organization or the company where he works. However, this calculation does not represent the human capital the employee has so that the effort to explore the potential for employee human capital is a human capital investment to encourage employees to 
make maximum contributions with all human capital in the form of knowledge, skills and maintaining health so that they can work optimally in the organization, which, ultimately, encourages overall organizational performance. So that the compensation paid to individuals who contribute to the organization is equal to the value of the contribution the company realizes. And the return on human capital investment made by a company or organization is measured by the increase in the value of individual contributions before and after the human capital investment is made.

\section{Conclusion}

From the results of quantitative and qualitative content analysis, it can be concluded that human capital is strongly influenced by the human condition of the human being both psychologically and physically, which ultimately affects the success of human capital investment in encouraging the financial performance of an organization or company.

\section{References}

Blake, P., \& Gano-an, J. (2020). ADVANCING SUSTAINABILITY INNOVATION WITHIN THE ORGANIZATIONAL LEARNING SPHERE. JBFEM, 3(1), 23-32.

Boella, M.J., Turner, S.G. (2013). Human Resource Management in the Hospitality Industry: A Guide to Best Practice. London: Routledge.

Boxall, P., Purcell, J. (2015). Strategy and Human Resource Management. New York: Palgrave Macmillan.

Elo, M., Coy, I.M. (2018). Diaspora Networks in International Business. Cham: Springer.

Fonseca, T.,Faria, P.D., Lima, F. (2019). Human capital and innovation: the importance of the optimal organizational task structure. Research Policy, 48(3), 616-627.

Greenberg, A.G., Gullotta, T.P., Bloom, M. (2016). Social Capital and Community Well-Being: The Serve Here Initiative. Cham: Springer.

Lee, L.Y., Kartika, N. (2014). The influence of individual, family, and social capital factors on expatriate adjustment and performance: The moderating effect of psychology contract and organizational support. Expert Systems with Applications, 41(11), 5483-5494.

Machado, C., Davim, J.P. (2017). Productivity and Organizational Management. Berlin:Gruyter $\mathrm{GmbH}$.

Rodgers, W., Degbey, W.Y., Housel, T.J., Arslan, A. (2020). Microfoundations of collaborative networks: The impact of social capital formation and learning on investment risk assessment. Technological Forecasting and Social Change, 161(12), 1-16.

Silva, C.F.D, Albuquerque, A.P.G., Melo, F.J.C., Calábria, F.A., Medeiros, D.D. (2020). A fuzzy approach to the strategic development of human capital in the electric sector. Computers \& Industrial Engineering, 149(11), 1-13.

Suprapto, M.H., \& Verdyana, E. (2020). UNITY IN THE WORKPLACE: THE EFFECTIVENESS OF TEAMWORK TRAINING. Review of Behavioral Aspect in Organizations and Society, 2(1), 15 24.

Wright, P.M.(2020). Rediscovering the "Human" in strategic human capital. Human Resource Management Review, 1(9), 1-9. 